\title{
Choice of a Value Identification Method in Career Counselling
}

\author{
Anita Racene $^{1}$ Dr. paed., Mg. oec., Mg. ed., Vija Dislere ${ }^{2}$ Dr. paed. \\ Institute of Education and Home Economics, \\ Latvia University of Life Sciences and Technologies, Latvia \\ anita.racene@1lu.1v; Vija.Dislere@1lu.lv²
}

\begin{abstract}
The paper presents the results of research on the role of choice of a value identification method for career counselling. The research aim is to analyse the results of application of value identification methods in career counselling. To achieve the aim, the present research studied students of vocational education institutions and analysed the results of an exercise done by the students as well as analysed relevant theories. The study involved 111 students aged 17-30. The study identified that five most important values for the youth with regard to their career development were as follows: stability, satisfaction, security, freedom and money. The research findings contribute to an understanding of the role of application of value identification methods in career counselling and give insight into the most important values for the youth. Career specialists and personnel selection specialists could use the findings in their career counselling practices.
\end{abstract}

Keywords: values, value identification, career counselling, school education.

\section{Introduction}

To build up individual skills matching labour market requirements and contribute to socio-economic development of the country, an important role is played by career counsellors working with the youth. The right choice of a career counselling method is important, as it results in the right choice of professions by young individuals and their professional success.

Nowadays, career development is characterised as a dynamic process that involves self-realisation, the social environment, interaction and change. Career development is affected by a number of factors that could be divided into two categories:

- endogenous factors related to an individual's personality and potential - skills, interests, values, abilities and needs;

- exogenous factors - the economic situation in the country, employment, the labour market, family status and the number of children in the family.

Career development levels of individuals are very different. Some individuals are satisfied with doing simple jobs, which require no high qualification, for a long period, whereas others wish to educate themselves and take increasingly higher and more responsible job positions. This means that the selfrealisation needs of individuals are very diverse, very individual and change over the course of time. For this reason, the right choice of a method employed by a career counsellor in his/her career counselling is very important.

Career counsellors employ a particular value identification method suited for a particular situation and particular client categories and particular client problems. The right choice of a method and the interpretation of the counselling result could stimulate the client to make a decision based on his/her values; the counsellor could suggest alternative occupations, as well as shape an individual career growth plan, help the client to understand the world of employment, contribute to the choice of a right career path by the client, help the client to get better integrated into the social life and his/her professional life. Value identification methods help career counsellors to identify career counselling boundaries as well as act professionally, ethically and wisely in assessing any particular situation and identifying the particular kind of career guidance needed.

The choice of a method performing a value identification exercise gives the client an opportunity to identify and choose his/her key values, and the exercise helps the client to make choices, develops the client's mental ability and helps the client to aware and define as well as analyse life values.

The research aim is to analyse the results of application of value identification methods in career counselling. 


\section{Methodology}

The results of a value identification exercise done by students of vocational education institutions were analysed to achieve the research aim. The authors of the research requested students aged 17-30 to do a value identification exercise during a career counselling class. The study on the young individuals was done from 1 September 2017 to 30 June 2018, involving 111 individuals. The study aimed to analyse the results of a value identification exercise.

The specific research tasks are as follows:

- to theoretically discuss value identification theories;

- to analyse the results of a value identification exercise.

Theory on value identification methods was employed to perform the research tasks and achieve the research aim. Statistical data were processed employing statistical analysis methods and descriptive statistics in MS Excel. The exercise analysis method was employed to analyse a value identification exercise. The study on students was done at the following vocational education institutions located in Zemgale region: Jelgava Crafts Secondary School, Zalenieki Commercial and Crafts Secondary School and Jelgava Technical School.

\section{Results and discussion}

\section{Value identification theories}

Values are a basis on which an individual build on his/her own personal existence acceptable to himself/herself. Values become distinctive based on social behaviour patterns and personal experience gained since childhood and change because of various events and experiences in the life.

A change in values or their priorities is most often observed during adolescence and early adulthood when the individual, for example, begins studies at university, leaves the parent's home, starts his/her own family and/or begins a professional career. Such social changes promote the formation of new values (Domino, Domino, 2006). Each period in the individual's life is unique, it has its own value in terms of acquiring new experience needed for preparing for the next stage in his/her life. For this reason, each life stage has to be lived to the fullest, acquiring new experience, enriching one's attitudes and values and getting more familiarised with oneself in various life situations.

L. Gottfredson (1981), however, believes that the structural formation of a personality is affected by gender, social background, intelligence as well as interests and values and their interaction with the personality's notion of employment.

In career counselling, values are analysed in conjunction with other factors determining the choice of a profession, such as interests, abilities and personal traits, the identification of which helps the client to make decisions (Jigau, 2007).

R.L. Schalock (Schalock et al., 2002) considered "life" to be referring to important aspects of human existence, e.g. family, health and work, and "quality" to be associated to human values e.g. health, satisfaction and happiness. M.L. Wehmeyer (2013) described quality of life or life satisfaction as a multidimensional construct which refers to the possibilities to meet the needs of people and to the opportunities to pursue improvements in life. Hence, the personal assessment of life satisfaction is based on participants' own unique values and criteria (Cohen-Scali, Rossier, Nota, 2018, 45).

German philosopher Eduard Spranger's theory defines six types of ideal individuals based on their ways of thinking, lifestyles and most important and general values. Each of the types focuses on certain basic values (Spranger, 1928):

1) theoretical - truth discovery and systematic thinking;

2) economic - usefulness and practicality, including the accumulation of wealth;

3) esthetical - beauty, the harmony of form and art;

4) social - relationships with other individuals;

5) political - desire for power and influence on others;

6) religious - unity and an understanding of the universe.

Measured on a scale of values, the mentioned basic values are different for every individual in terms of importance, yet one of them is dominant. The choice of a particular occupation or profession is 
associated with the individual's system of values, as the individuals of the same profession usually share the same values and attitudes.

Occupations undergoing rapid change in the workplace, the apprenticeship model can slow adaptation or change in working methods, because of the prevalence of traditional values and norms being passed down. Traditional values and norms around teaching are increasingly in conflict with external forces such as new technology and the massification of higher education (Bates, 2016, 90). During the past century, shifting social contexts moved perspectives to new vantage points from which to derive different social practices, again including career counselling (Savickas, 2015). Career counselling plays an important role in raising young people's awareness of values in their career development.

After the individual's values have been identified, the individual is likely to be less uncertain about the future and more engaged in developing the professional identity.

Career choice theories consider a profession to be productive and stable if it is:

- chosen by the client him/herself and the client is fond of it;

- selected from among many possible alternatives;

- consistent with the client's abilities, interests and values;

- supported by individuals being important to the client.

Eli Ginzberg's Professional Choice Theory suggests the following most important factors affecting the choice of a career: the living environment, educational attainment, individual values and personal traits (Ginzberg et al., 1951). The choice of a profession is affected by the quality of the choice in terms of career values.

Values are defined as motivational drivers and criteria, based on which goals are set. The criteria that are consistent with values are as follows (Gibson, Mitchell, 1981):

- free choice - from among alternatives, after each one has been analysed;

- preservation, appreciation - careful observance of one's own values; the choice of the values causes satisfaction and a wish to publicly declare them;

- actions - to be integrated into the behavioural pattern, making choices several times throughout the lifetime.

Choosing certain values means making a choice of goals and behaviours that are preferred or are superior to the others. Values, interests and needs pertain to various motivational aspects. Compared with interests, values are more general, abstract and fundamental. Values are determined later than interests, during adolescence, while needs dominate persistently. Interests might take the form of choice of values insofar as particular situations or actions are a means of achieving a certain result.

An individual's sense of values develops not only during learning but also when communicating with the family, friends and colleagues; besides, the mass media also shape it (Kramer, 2010). Value system determines the quality of the decisions, so the school creates a model of cooperation between teachers and parents that provide students a unified information space of knowledge. The school is responsible for the productive cooperation and partnership between the school and the family (Vanaga, Balode, 2016, 120).

M. Rokeach (1974) distinguishes a series of 18 "fundamental" values that refer to personal goals (e.g. "to live a peaceful life") or social goals (e.g. equality, freedom) and 16 "useful" values that pertain to a set of behaviours making positive moral implications in demonstrating certain traits (ambition, honesty, responsibility).

J. Perron (1981) writes about five categories of values: status (a wish to be admired, an adequate job position, high income), achievements (a wish to do creative activities that allow self-expressing oneself), the climate (a wish for an organised and pleasant environment), risk (a wish for competition and unpredictable situations) and freedom (a wish to be independent).

D.E. Super created The Inventory of Professional Values comprised of 15 categories (Super, 1980; 1990; Jigau, 2007):

- altruism (possibility to benefit others);

- aesthetical values (take the form of activities allowing achieving aesthetical goals and contributing to making a better world we live in); 
- intellectual stimulation (pertains to professions allowing for autonomous thinking and continuous learning);

- professional achievements (reflect the appreciation of the profession that gives satisfaction from a well-done job);

- independence (in professions allowing the individual to work according to an individual plan and at his/her own pace);

- prestige (in professions attaching importance to those that perform them and gain respect of the others);

- leading others (in professions allowing the possibility of planning and organising the work of others);

- economic advantages (reflect the orientation towards well-paid professions);

- professional security (in professions where the individual is sure to hold on to a job);

- work atmosphere (refers to satisfactory work conditions);

- relationships with superiors (work supervised by a fair boss with whom the individual gets along well);

- relationships with colleagues (activity offering the opportunity of good social relations with the colleagues);

- lifestyle (in professions where employees can organize their life the way they like);

- variety (activities with diverse operations);

- creativity (in professions that involve making new things or products.

As regards career counsellors, R.V. Peavy (2004) indicated the values they need to be able to advise others: wholeness, perfection, completeness, justice, vitality, richness, simplicity, beauty, goodness, uniqueness, openness, playfulness, truth, honesty, reality and self-sufficiency. Wisdom refers to an intelligent and ethical perspective, creativity and clear consciousness. The mentioned values could be excellent traits of a provider of advice.

\section{Value identification methods}

If an individual applies value identification tools in a proper way, there is a high probability to transpose conflicts or contradictions/disagreements into a positive decision and the life of an individual, from the social perspective, becomes satisfactory and constructive. D. Brown and L. Brooks developed a series of steps to be done to identify a client's values with the help of a counsellor (Brown, Brooks, 1991):

- informing the client about the role of values, motivation and satisfaction, related to the job, in making decisions;

- applying formal and informal value identification tools;

- making a list of the client's values;

- discussing disagreements caused by contradictory values;

- assessing the influence of values on the choice of a profession or changes in the client's life.

The list of values has to be analysed with regard to the client's interests, abilities and roles in the life. If any contradictions emerge, they have to be discussed with a counsellor to identify appropriate ways of harmonisation. For example, if the client seeks a job, the counsellor has to offer job alternatives that could be consistent with the client's values.

Value identification methods are employed both in individual and in group counselling. There are exercises that, if done individually or together with a counsellor, can determine the behaviour of the client. In individual counselling, the following aspects are of great importance:

- establishing and maintaining a relationship with the client;

- identifying and examining the consequences of a choice made;

- making decisions by the client;

- making the client aware of how it is important to be proactive regarding the decisions.

Value identification tools have great potential in group counselling. Value identification methods are employed to inform the client and develop his/her communicative and interpersonal relation skills. Exercises done by a group of clients contribute to their self-knowledge and shape a particular behaviour on the part of the clients. The methods allowing clients to compare, examine and find arguments in 
favour of their own values, interests and behaviours, despite the rules other individuals impose on them, are particularly effective. L.R. Gibson and M.H. Mitchell discovered similarities between the value identification process and counselling stages (Table 1).

Table 1

Key similarities between the value identification process and counselling stages

(Gibson, Mitchell, 1981)

\begin{tabular}{|l|l|l|}
\hline No & \multicolumn{1}{|c|}{ Value identification } & \multicolumn{1}{c|}{ Counselling } \\
\hline 1 & $\begin{array}{l}\text { Getting familiarised with each other: mutual } \\
\text { trust and an atmosphere of acceptance and } \\
\text { open communication are created }\end{array}$ & $\begin{array}{l}\text { Establishing a relationship: the sense of support } \\
\text { is created in the client that helps to explain the } \\
\text { client why he/she needs counselling }\end{array}$ \\
\hline 2 & Creating a self-image & $\begin{array}{l}\text { Identifying and examining the concerns of the } \\
\text { client }\end{array}$ \\
\hline 3 & Identifying the values of the client & $\begin{array}{l}\text { Identifying and examining the various options } \\
\text { available to the client }\end{array}$ \\
\hline 4 & $\begin{array}{l}\text { Individuals are assisted with choosing one } \\
\text { of the alternatives and confirm their values } \\
\text { after its consequences are assessed }\end{array}$ & $\begin{array}{l}\text { Client makes a decision after all alternatives to } \\
\text { the options have been analysed }\end{array}$ \\
\hline 5 & $\begin{array}{l}\text { Individuals are assisted with setting goals } \\
\text { and activities aligned with their values }\end{array}$ & $\begin{array}{l}\text { Implementing the decision: the goal is set, and } \\
\text { the client begins acting }\end{array}$ \\
\hline
\end{tabular}

After the values of the client have been identified and examined during counselling, the career counsellor reveals the kind of behaviour of the client and what things are important in the client's life. The responsibilities of the career counsellor with regard to value identification methods are as follows (Gibson, Mitchell, 1981):

- to understand one's own values and the way the values differ from those of colleagues and clients;

- to accept the fact that the client has the right to have different values;

- to abandon a moralising tone or tendency to engage in activities that might deter the client from examining and reflecting on his/her values;

- to avoid judging the client and create a positive and open atmosphere facilitating the use of value identification methods;

- to identify what impacts the counsellor's values could make on the client.

Based on the authors' experience in previous studies the main problems were associated with the lack of information, the existence of several alternatives, no awareness of students' interests, abilities and values as well as the influence of one's socio-economic conditions on making a career decision. The Guidance Model (Briska, Dislere, 2018, 349) and its methodology focus on self-guidance through all the problematic matters, allowing students to deal with the themes which present the biggest problems. After summarising the findings of several authors, it can be concluded that self-directed learning is a process where individuals ascertain their values, interests, abilities and talents, set their learning and career goals, choose and implement a learning strategy, plan their work and do reflection on their own initiative. A career counsellor is an assistant in the student's personality development and promotes the students' activity in identifying and enhancing their values.

\section{Analysis of the results of a value identification exercise}

The study on students was carried out from 1 September 2017 to 30 June 2018, giving an exercise to 111 students of vocational secondary schools during individual and group career counselling classes "Value Identification". A questionnaire was designed using the questionnaire forms available at www.visidati.lv in order that it was easy and convenient for the respondents to fill in their questionnaires. The data were processed employing the statistical grouping method and descriptive statistics in MS Excel (Paura, Arhipova, 2002). Employing the MS Excel descriptive statistics tool allowed identifying the statistical characteristics of the youth who participated in the study (Table 2). 


\section{Statistical characteristics of the youth who participated in the study}

\begin{tabular}{|l|l|c|}
\hline No & Statistical measures & Sample characteristics \\
\hline 1 & Average & 23.41 \\
\hline 2 & Mode & 19 \\
\hline 3 & Median & 23 \\
\hline 4 & Range & 13 \\
\hline 5 & Minimum & 17 \\
\hline 6 & Maximum & 30 \\
\hline 7 & Number of respondents & 111 \\
\hline
\end{tabular}

As shown in Table 2, the number of participants was 111 who took part in the study; the range of age was 13 years, the mode was equal to 19 , the median was 23 and the average was 23.41 . The breakdown of the respondents by gender was as follows: $50 \%$ women, $50 \%$ men.

The given exercise required the respondents to rank the values related to their professional lives by importance with 1 being the most important and 25 being the least important. The results are summarised in (Table 3).

Table 3

Results of the value identification exercise

\begin{tabular}{|l|c|l|c|}
\hline \multicolumn{1}{|c|}{ Value } & Position & \multicolumn{1}{c|}{ Value } & Position \\
\hline Stability & $\mathbf{1}$ & Creativity & 13 \\
\hline Satisfaction & $\mathbf{2}$ & Recognition & 14 \\
\hline Security & $\mathbf{3}$ & Independence & 15 \\
\hline Freedom & $\mathbf{4}$ & Gratitude & 16 \\
\hline Money & $\mathbf{5}$ & Self-realisation & 17 \\
\hline Joy & 6 & Feeling of affiliation & 18 \\
\hline Result & 7 & Remuneration & 19 \\
\hline Achievements & 8 & Cooperation & 20 \\
\hline Courage & 9 & Challenges & 21 \\
\hline Help to others & 10 & Status & 22 \\
\hline Support & 11 & Opportunity to influence & 23 \\
\hline Proficiency & 12 & Power & 24 \\
\hline
\end{tabular}

According to the study data, the top five values were as follows: stability, satisfaction, security, freedom and money.

Using value identification exercises in career counselling helps the youth to:

- get familiarised with and comprehend themselves with regard to what is important and what is not important;

- $\quad$ easily adapt to daily life requirements at school or in the family or a group;

- develop personal and professional projects;

- identify the reasons of professional dissatisfaction.

Career counsellors have an opportunity to identify the reasons of low self-motivation and role conflicts (e.g. between the profession and the family). During career counselling, the youth give answers and are spontaneously engaged in value identification exercises.

The task of a counsellor is to explain the clients that the exercise results show only a tendency, to outline the diagnostics results in a comprehensible way, but to interpret the results neutrally (Racene, 2017). 
Value identification methods are particularly useful if working with:

- teenagers - career counsellors help them to make decisions and set realistic professional projects by analysing interaction among personal factors (values, efforts, interests, personal traits, competence, abilities) and environmental factors (family hopes, teacher opinions, cultural, economic and social aspects) (Jigau, 2007);

- young individuals and adults who seek employment or wish to learn a new profession that could be consistent with their values, personalities and interests. During career counselling, the professional values and interests of a client are discussed and assessed whether they are consistent with the client's life interests, abilities and roles.

\section{Conclusions}

The choice of a particular occupation or profession is associated with the individual's system of values. After the individual's values have been identified, the individual is likely to be less uncertain about the future and more engaged in developing the professional identity.

The right choice of a method and the interpretation of the counselling result could stimulate the student to make a decision based on his/her values; the counsellor could suggest alternative occupations, as well as shape an individual career growth plan, help the client to understand the world of employment, contribute to the choice of a right career path by the client, could suggest self-directed guidance model for promoting career decision-making, organizes the productive cooperation and partnership between the school and the family, help the student to get better integrated into the social life and his/her professional life.

Value identification methods help career counsellors to identify career counselling boundaries as well as act professionally, ethically and wisely in assessing any particular situation and identifying the particular kind of career guidance needed.

\section{Bibliography}

1. Bates A.W. (2016). Teaching in a Digital Age. Guidelines for designing teaching and learning. Canada, Burnaby BC: Simon Fraser University. Retrieved from https://teachonline.ca/sites/default/files/pdfs/teaching-in-a-digital-age_2016.pdf

2. Briska L., Dislere V. (2018). Guidance Model for Promoting Self-Directed Career DecisionMaking by Secondary School Students. In V. Dislere (Ed.), The Proceedings of the International Scientific Conference Rural Environment. Education. Personality (REEP), 11. Jelgava: LLU TF, 344-350. Retrieved from http://llufb.1lu.lv/conference/REEP/2018/Latvia_REEP_2018_proceedings_ISSN2255808X.pdf

3. Brown D., Brooks L. (1991). Career counselling techniques. Boston: Allyn, Bacon.

4. Cohen-Scali V., Rossier J., Nota L. (Eds.). (2018). New perspectives on Career Counselling and Guidance in Europe: Building careers in changing and diverse societies. Cham, Switzerland: Springer International Publishing AG.

5. Domino G., Domino M.L. (Eds.). (2006). Psychological testing: An introduction. New York, NY, US: Cambridge University Press.

6. Gibson R.L., Mitchell M.H. (1981). Introduction to guidance. New York: Mac Millan Publishing Co. Inc.

7. Ginzberg E., Ginsburg S.W., Axelrad S., Herma J.L. (1951). Occupational choice: An approach to a general theory. New York: Columbia University Press.

8. Gottfredson L.S. (1981). Circumscription and compromise: A developmental theory of occupational aspirations. Journal of Counselling Psychology, 28(6), 545-579.

9. Jigau M. (Ed.). (2007). Career Counselling - Compendium of Methods and Techniques. Bucharest: AFIR. Retrieved from

http://www.rajaleidja.ee/public/Suunajauus/Career_Counselling._Compendium_of_Methods_an d_Techniques.pdf

10. Kramer M.W. (2010). Organizational Socialization. Cambridge, UK: Polity Press.

11. Paura L., Arhipova I. (2002). Neparametriskas metodes: SPSS datorprogramma (Nonparametric Methods: SPSS software). Jelgava: LLKC. (in Latvian).

12. Peavy V.R. (2004). SocioDynamic Counselling: A Practical Approach to Meaning Making. Ohio, USA: Taos Institute Publications. 
13. Perron J. (1981). Valeurs et choix en education (Values and choices in education). St. Hyacinthe, Quebec: Edisem. (in French)

14. Racene A. (2017). Importance of Goal-Setting Tasks in Career Counselling. In V. Dislere (Ed.), The Proceedings of the International Scientific Conference Rural Environment. Education. Personality (REEP), 10. Jelgava: LLU TF, 442-450. Retrieved from http://lufb.llu.lv/conference/REEP/2017/Latvia-Univ-Agricult-REEP-2017_proceedings-442-450.pdf

15. Rokeach M. (1974). The Nature of Human Values. Political Science Quarterly, 89(2), 399-401.

16. Savickas M.L. (2015). Career counseling paradigms: Guiding, developing, and designing. In P.J. Hartung, M.L. Savickas, W.B. Walsh (Eds.), APA handbook of career intervention: Volume 1: Foundations, Washington, DC: American Psychological Association, 129-143.

17. Schalock R.L., Brown I., Brown R., Cummins R.A., Felce D., Matikka L., Keith K.D., Parmenter T. (2002). Conceptualization, measurement, and application of quality of life for persons with intellectual disabilities: Report of an international panel of experts. Mental Retardation, 40(6), 457-470. Retrieved from

https://pdfs.semanticscholar.org/e542/e17038b0ab3f3be8d10f1b3744cda0e9906d.pdf

18. Spranger E. (1928). Types of men. The psychology and ethics of personality. Oxford, England: Niemeyer.

19. Super D.E. (1980). A life-span, life-space approach to career development. Journal of Vocational Behavior, 16(3), $282-298$.

20. Super D.E. (1990). A life-span, life-space approach to career development. In D. Brown, L. Brooks (Eds.), Career choice and development: Applying contemporary theories to practice. San Francisco, CA: Jossey-Bass, $197-261$.

21. Vanaga A., Balode M. (2016). Succession of Fostering Learning Skills in Preschool and School. In V. Dislere (Ed.), The Proceedings of the International Scientific Conference Rural Environment. Education. Personality (REEP), 9. Jelgava: LLU TF, 114-121. Retrieved from $\mathrm{http}: / / 1$ ufb.llu.lv/conference/REEP/2016/Latvia-Univ-Agricult-REEP-2016proceed2255-808X.pdf

22. Wehmeyer M.L. (Ed.) (2013). The Oxford handbook of positive psychology and disability. New York, NY, US: Oxford University Press. 